\title{
Genetic variation in relic and isolated populations of Chionanthus retusus (Oleaceae) of Tsushima Island and the Tôno region, Japan
}

\author{
Akiko Soejima ${ }^{1}$, Masayuki Maki $^{2}$, and Kunihiko Ueda ${ }^{3, *}$ \\ ${ }^{1}$ College of Integrated Arts and Sciences, Osaka Prefecture University, Sakai, Osaka 599-8531, \\ ${ }^{2}$ Department of Biology, Fukuoka University of Education, 729-1 Akama, Munakata, Fukuoka 811-4192, and \\ ${ }^{3}$ Deptment of Biology, Faculty of Science, Kanazawa University, Kanazawa, Ishikawa 920-1192, Japan
}

(Received 5 August 1997, accepted 3 December 1997)

Genetic variation in an endangered tree species, Chionanthus retusus, was examined using enzyme electrophoresis. This species occurs in East Asia from Japan to Taiwan and southern China. In Japan, however, it occurs only in two restricted areas: at the northernmost tip of Tsushima Island between Japan and Korea, and in the eastern Gifu Prefecture (Tôno region) of central Honshu. In the Tôno region, the habitat of $C$. retusus is becoming fragmented under the influence of human activity and each stand contains a few individuals of $C$. retusus, while the population on Tsushima consists of approximately 1000 individuals. From the fossil evidence, $C$. retusus has been distributed continuously including the both two regions, and the present distribution is apparently relic in Japan. In contrast to the Tôno population, the population of Tsushima seems to be stable. Comparing the genetic diversity and differentiation of the populations between these two regions should shed light on how a relic woody long-lived plant keeps and/or looses its genetic diversity, and how a population differentiates from other disjunct populations.

Allozyme electrophoresis of 18 loci for the Tôno region indicated that $22.2 \%$ of the loci are polymorphic $(P)$ with a gene diversity of $(h) 0.087$. The population of Tsushima has $38.9 \%$ polymorphic loci and a gene diversity of 0.149 . We could not find any spatial genetic structure of $C$. retusus in the Tôno region by spatial autocorrelation analysis. These results suggest that considerable genetic variation is still present in the Tôno region and the influence of the recent habitat fragmentation seems not so large, yet. Because $C$. retusus is a long-lived tree, the population history may hinder the effect of the fragmentation at present.

The genetic diversity $\left(\mathrm{G}_{\mathrm{ST}}\right)$ between the populations of the Tôno and Tsushima is 0.280 , showing the genetic differentiation between these two regions has occurred.

\section{INTRODUCTION}

Genetic diversity within populations of a relic isolated plant such as Chionanthus retusus is very important for the species preservation. Only a few studies have analyzed the genetic divergence and structure of relic and narrowly isolated woody plant species (e.g., McDonald and Hamrick, 1996). Previous studies of the genetic diversity in rare plants have reported a significant correlation between the amount of allozyme variation and the actual number of individuals in a population (Moran and Hopper, 1983; McCleanaghan and Beauchamp, 1986; Billington, 1991; van Treuren et al., 1991). These data indicate that the effective population size is directly proportional to the number

\footnotetext{
* Corresponding author.
}

of individuals in a given population. Geographic range also was shown to have a significant effect on levels of genetic diversity within species. Species with limited geographic ranges often occur in small isolated populations where gene flow is limited and, as a result, genetic variation within populations is reduced (Karron, 1987; Hamrick et al., 1992).

The distribution area of $C$. retusus in the Tôno region is $55 \mathrm{~km}$ (ENE-WSW) by $30 \mathrm{~km}$ (NNW-SSE) (Fig. 1). In Tsushima Island, it occurs solely in a $1 \times 1 \mathrm{~km}$ site (Fig. 2). According to the extensive field survey of Ohta (personal communication), there are at most 200 of the trees in the Tôno region, and approximately 1,000 on Tsushima. In Tôno, a single or a few trees exist in most stands (Fig. 1), but in Tsushima they grow as dominant species in thickets.

On the other hand, fossils of Chionanthus have been dis- 
covered in several localities of Japan, including the Chiba Prefecture (Cretaceous), Kushiro of Hokkaido (Oligocene), Saitama Prefecture (middle Pleistocene) and Hyogo Prefecture (late Pleistocene). Holocene fossils have been discovered in Mino-kamo in the Gifu Prefecture, which is adjacent to the Tôno region (Noshiro and Fujine, 1996) (Fig. 1). Thus the present distribution of $C$. retusus in the Tôno region is apparently relic of an ancient distribution that was continuous from Japan to China and Taiwan via Tsushima and the Korean Peninsula.

The habitat of $C$. retusus is rapidly declining under the influence of human activity in the Tôno region, and the population is becoming increasingly fragmented. On the other hand, the population of Tsushima does not appear to be declining at present. Comparing the genetic diversity and differentiation of the populations between these two regions should shed light on how a relic woody long-lived plant keeps and/or looses its genetic diversity, and how population differentiation occurs between disjunct populations. Accordingly, we conducted allozyme analyses to estimate the genetic diversity of the populations in the Tôno region, and to differentiate these populations from that of Tsushima Island.

C. retusus is, at least morphologically, androdioecious (Ohta, 1983; Ueda, 1996) and entomophilous. Because the habitat is fragmented and stands are isolated each other, a large part of gene flow between stands may be depend on the frequency of insect movement in the Tôno region. Limited gene flow must result in differentiation of genetic structure by the effect of the isolation by distance. Spatial autocorrelation analysis (Sokal and Oden, 1978) is used to examine whether or not genetic structure exists within the Tôno region.

\section{MATERIALS AND METHODS}

Collections. Chionanthus L. is a genus within the Oleaceae. Although Stearn (1976) considered Southeast Asian Linociera to be congeneric with temperate Chionanthus s.str., Baas et al. (1988) pointed out that Chionanthus s.str. is easily recognized as a natural taxon and can be easily distinguished from Linociera. Here, we defined the genus Chionanthus in a strict sense, as comprising two disjunctively distributed tree species. C. retusus Lindl. et Paxton occurs in East Asia from Japan to Taiwan and southern China, and $C$. virginica L. is distributed in eastern North America. In Japan, however, C. retusus occurs only in two restricted areas: at the northernmost tip of Tsushima Island between Japan and Korea, and in the eastern Gifu Prefecture (Tôno region) of central Honshu (Figs. 1 and 2).

Seventy-eight individuals from 32 stands of the Tôno region and 105 individuals from the Waniura population on Tsushima island were sampled as shown in Table 1 (Figs. 1 and 2). The population of the Tôno region is divided into four subpopulations I-IV according to geographic location
(Fig. 1).

Electrophoresis. For electrophoresis, the leaf material of individual plants was ground in $1 \mathrm{ml}$ of extraction buffer (Kato, 1990), with slight modification: i.e., 0.1 M tris-HCl pH7.5, 70 mM 2-mercaptoethanol, $26 \mathrm{mM}$ sodium metabisulfate, $11 \mathrm{mM}$ L-ascorbic acid, and $4 \%$ soluble polyvinylpyrrolidone with an average molecular weight of 40,000. Enzymes were resolved in $12 \%$ starch gel (Sigma) using two buffer systems. System I had a gel buffer containing 0.033 $\mathrm{M}$ tris, 0.005 M citric acid, 0.004 M lithium hydroxide, 0.3 $\mathrm{M}$ boric acid with $\mathrm{pH}$ adjusted to 7.6 and an electrode buffer of $0.039 \mathrm{M}$ tris, and $0.263 \mathrm{M}$ boric acid with $\mathrm{pH}$ adjusted to 8.0 (Soltis and Soltis, 1987). System II consisted of an electrode buffer containing $0.065 \mathrm{M}$ L-histidine (free base) and $0.007 \mathrm{M}$ citric acid (monohydrate) adjusted to $\mathrm{pH}$ 6.5. The gel buffer was a 1 : 3 dilution of the electrode buffer (Cardy et al., 1981). System I resolved alcohol dehydrogenase (ADH, EC 1.1.1.1.), glucosephosphate isomerase (= phosphoglucoisomerase) (PGI, EC 5.3.1.9), leucine aminopeptidase (LAP, EC 3.4.11.-), and triosephosphate isomerase (TPI, EC 5.3.1.1). System II was employed to resolve malate dehydrogenase (MDH, EC 1.1.1.37), 6-phosphogluconate dehydrogenase (6PGDH, EC 1.1.1.44), [NADP] glyceraldehyde3-phosphate dehydrogenase ([NADP]G3PDH, EC 1.2.1.12), and phosphoglucomutase (PGM, EC 2.7.5.1). Staining schedules followed the methods of Soltis et al. (1983).

Statistical analysis. Levels of genetic diversity were calculated for the populations according to a number of parameters including proportion of polymorphic loci $(P)$, number of alleles per polymorphic locus $(A p)$, number of alleles per locus $(A)$, and mean gene diversity per locus (h). Nei's (1972) genetic identity and genetic distance were calculated for each pair of populations and subpopulations. Gene diversity values within and among populations was calculated with Nei's (1973) genetic diversity statistics: $H_{T}$ = total genetic diversity per locus, $H_{S}=$ mean genetic diversity within populations, and $G_{S T}=$ coefficient of gene differentiation. These values were calculated among each pair of the four subpopulations of the Tôno region and between the Tôno and Tsushima populations.

To examine the genetic structure of the C. retusus population in the Tôno region more explicitly, we also performed a spatial autocorrelation analysis based on the allozyme genotypes. Spatial autocorrelation analysis features the advantages of other descriptive population genetic statistics, such as $F$ - statistics, in that it requires no a priori assumption of genetic structure, and it allows for determination of the structure at any spatial scale (Heywood, 1991). In most previous studies, spatial autocorrelation statistics have been utilized to analyze intra-populational genetic structure. However, spatial autocorrelation analysis may be useful for detection of spatial genetic structure across a local distribution area such as the Tôno region where $C$. 

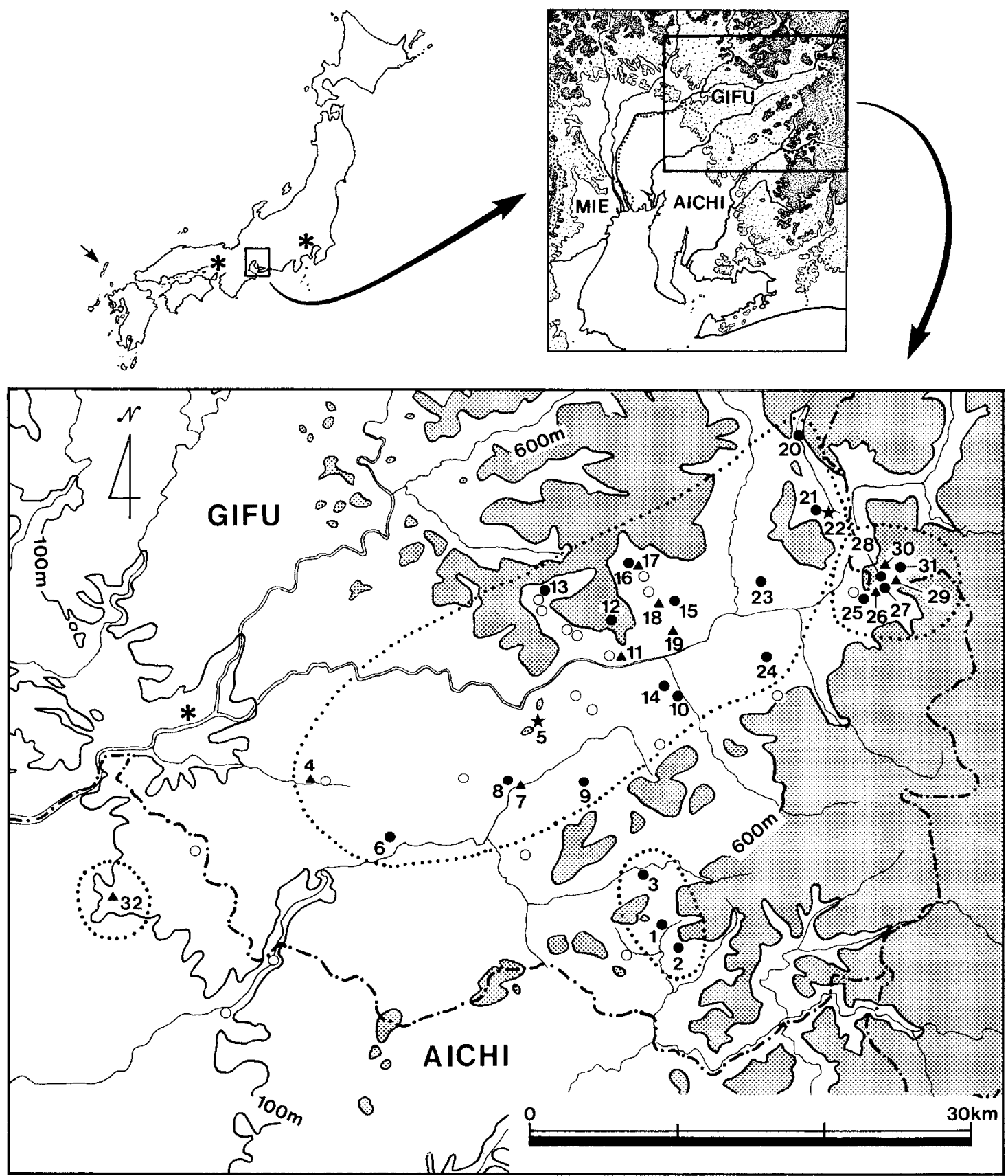

Fig. 1. Distribution map of nearly all the localities of Chionanthus retusus in Tôno region. Numbers beside symbols correspond to numbers in Table 1. Dotted lines indicate subpopulations. Closed circle: locality of a single isolated tree. Triangle: locality where more than two trees grow, but natural regeneration is not expected because the habitat is completely controlled artificially. (cf., concrete or lawn placing.) Star: locality where more than two trees grow, and natural regeneration can be expected. Open circle: locality where materials not collected. Quaternary fossils of C. retusus reported (see text) are indicated in the map as asterisks. The left top arrow indicates Tsushima Island.

retusus is distributed widely and continuously.

The position of all stands of $C$. retusus in the Tôno region were mapped on several 1/25,000 topographical maps of the Geographical Survey Institute (GIS) of Japan. For each stand we calculated allele frequencies of polymorphic loci and assigned them a location on the map. When only one individual was sampled in a stand, the genotype data were coded such that allele frequency values of $0.0,0.5$, or 1.0 were assigned to the location for one allele of each locus. Moran's I values (Sokal and Oden, 1978) were calculated using the SAAP program (ver 4.3) written by D. Wartenberg (1989) for 10 inter-stand distance classes. These 10 distance classes are $0<5,5<10,10<15,15<20$, $20<25,25<30,30<35,35<40,40<45$, and $>45 \mathrm{~km}$. 


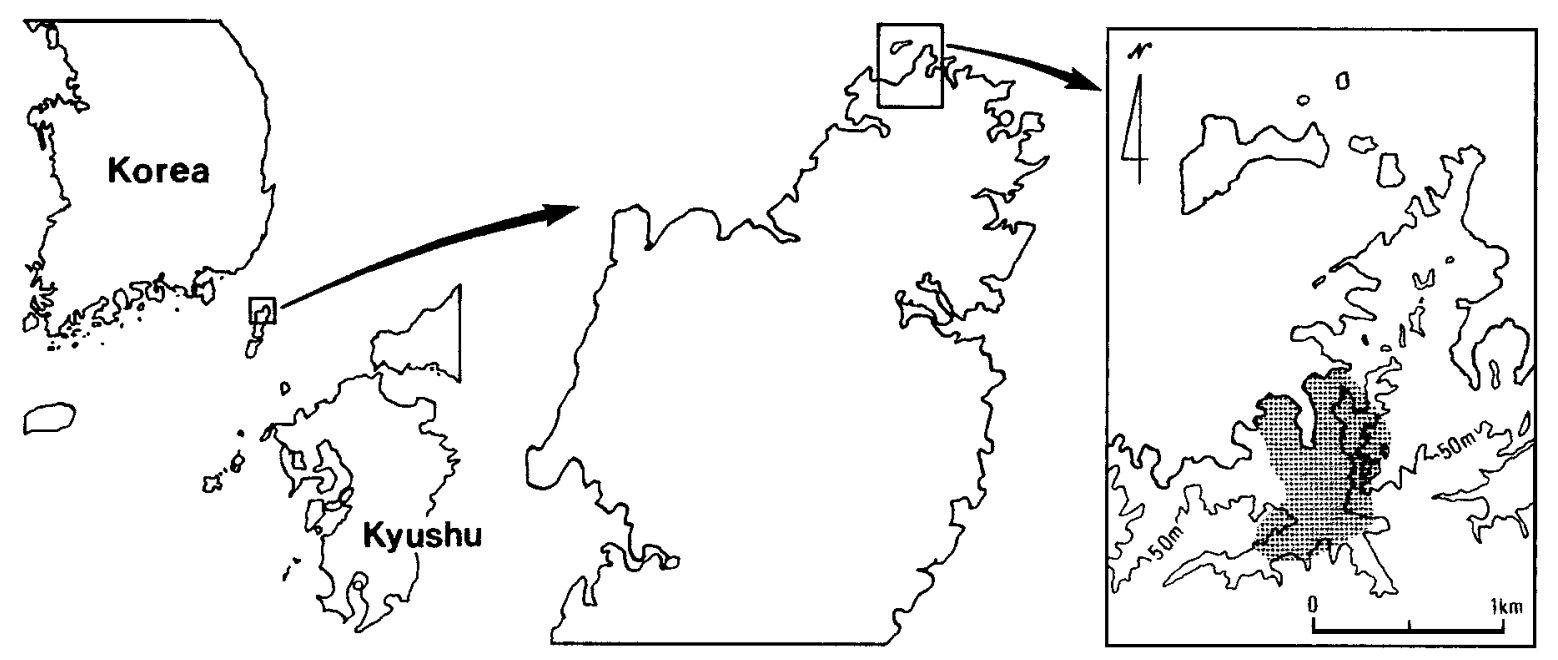

Fig. 2. Distribution map of Chionanthus retusus in Tsushima Island. C. retusus can be found only in shaded area.

Table 1. Materials for analyses: locality, date and collector

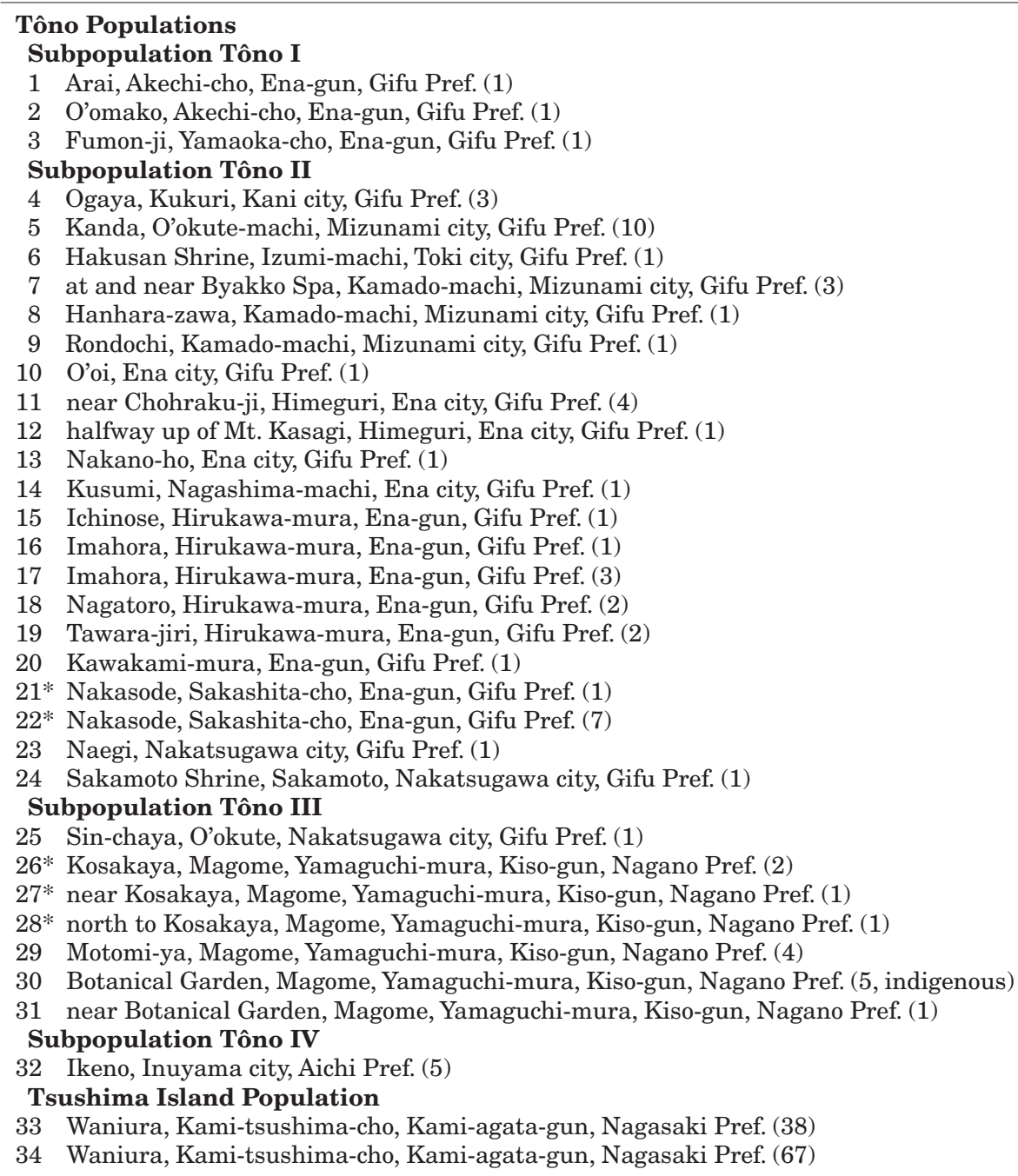

May 23-27, $1991 \mathrm{KU}$ May 23-27, $1991 \mathrm{KU}$ May 23-27, $1991 \mathrm{KU}$

May 23-27, $1991 \mathrm{KU}$ May 23-27, $1991 \mathrm{KU}$ May 23-27, $1991 \mathrm{KU}$ May 23-27, $1991 \mathrm{KU}$ May 23-27, $1991 \mathrm{KU}$ May 23-27, $1991 \mathrm{KU}$ May 23-27, $1991 \mathrm{KU}$ May 23-27, $1991 \mathrm{KU}$ May 23-27, $1991 \mathrm{KU}$ May 23-27, $1991 \mathrm{KU}$ May 23-27, $1991 \mathrm{KU}$ May 23-27, $1991 \mathrm{KU}$ May 23-27, $1991 \mathrm{KU}$ May 23-27, $1991 \mathrm{KU}$ May 23-27, $1991 \mathrm{KU}$ May 23-27, $1991 \mathrm{KU}$ May 23-27, $1991 \mathrm{KU}$ May 23-27, $1991 \mathrm{KU}$ May 23-27, $1991 \mathrm{KU}$ May 23-27, $1991 \mathrm{KU}$ May 23-27, $1991 \mathrm{KU}$

May 23-27, $1991 \mathrm{KU}$ May 23-27, $1991 \mathrm{KU}$ May 23-27, $1991 \mathrm{KU}$ May 23-27, $1991 \mathrm{KU}$ May 23-27, $1991 \mathrm{KU}$ May 23-27, $1991 \mathrm{KU}$ May 23-27, $1991 \mathrm{KU}$

May 23-27, $1991 \mathrm{KU}$

May 17, 1992 SM May 23-24, 1996 KU \& MM

The parentheses mean the numbers of plants examined. KU, Kunihiko Ueda. MM, Masayuki Maki. SM, Satoko Matsumoto. *,21-22, and 26-28 were treated as a single site respectively in the case of spatial autocorrelation analysis. 
Whether or not each $I$ value deviated significantly from the expected value $E(I)=(N-1)-1$, where $N$ is the number of individuals, was also tested by SAAP. The $I$ values that are significantly greater than $E(I)$ indicate that scores are more similar than expected by chance. The overall significance of individual correlograms were tested using Bonferroni's criteria (Sakai and Oden, 1983).

\section{RESULTS}

Field observation. Tokai Hilly Land elements, of which C. retusus is a member, are endemic or semi-endemic to the circum Ise Bay area (of which the Tôno area is at the center) or are considered relic taxa found in this region (Ueda, 1989). Some species usually grow in open or sunny wetland, and C. retusus is not an exception. In the Tôno region, C. retusus always grows in rocky or stony soil in sparse thickets as a canopy tree, along underground flow or streams, or on cliffs. On Tsushima Island, the plant grows rather densely on steep rocky cliffs or along narrow rocky ridges.

Although the area of the Tsushima population is very small, we can observe morphological variation in features such as size and shape of leaves, entire or serrate leaves, hair density and length in young leaves, shape of corolla, and so on. On the other hand, the Tôno population, despite its comparatively larger distribution, shows little variation: in particular, the leaves are always entire and round.

Isozyme analysis. C. retusus was reported as $n=46$ using pollen mother cell (Chuang et al., 1962), but Sax and Abbe (1932) reported $n=23$ by the same method. Taylor (1945) counted $2 n=46$ using a leaf for $C$. virginica. These results imply the basic chromosome number of $C$. retusus is $x=23$, and suggest the possibility of the existence of both diploid and tetraploid. In the present study, however, the enzyme patterns show no evidence for polyploidization in $C$. retusus. We could find neither fixed heterozygosity nor dosage differentiation of certain bands, and all the enzyme systems could be successfully interpreted under the assumption that $C$. retusus is diploid.

The eight enzyme systems resolved were interpreted as being encoded by the following 18 putative loci: Adh-1, Adh2, G3pdh, Lap, Mdh-1, Mdh-2, Mdh-3, Mdh-4, 6Pgdh-1, 6Pgdh-2, Pgi-1, Pgi-2, Pgm-1, Pgm-2, Tpi-1, Tpi-2, Tpi-3 and Tpi-4. The allozymes encoded by Adh-1 and Adh-2 could not be scored for the subpopulation Tôno-I due to poor resolution (Table 2).

Among the 18 loci scored, there was no variation for Pgi1, Tpi-1, 6pgdh-1, 6pgdh-2, G3pdh, Tpi-3, Tpi-4,Adh-1, Mdh2 , or $M d h-3$. The other eight loci were polymorphic, with two to four alleles. The allelic frequencies at polymorphic loci are given in Table 3. The eight polymorphic loci have a total of 22 alleles. Among the 22 alleles, three (Pgm-2c, $P g m-2 d$, and $M d h-4 b)$ are present only in the Tôno region,
Table 2. The numbers of the individuals scored for each allozymic locus

\begin{tabular}{lcccccc}
\hline \hline & & \multicolumn{3}{c}{ Tôno } & \multicolumn{2}{c}{ Tsushima } \\
& I & II & III & IV & Total \\
\hline Pgi-1 & 3 & 46 & 14 & 4 & 67 & 105 \\
Pgi-2 & 3 & 46 & 14 & 4 & 67 & 105 \\
Pgm-1 & 3 & 53 & 15 & 5 & 76 & 104 \\
Pgm-2 & 3 & 53 & 15 & 5 & 76 & 104 \\
Tpi-1 & 3 & 49 & 13 & 5 & 70 & 105 \\
Tpi-2 & 3 & 49 & 13 & 5 & 70 & 105 \\
Tpi-3 & 3 & 49 & 13 & 5 & 70 & 105 \\
Tpi-4 & 3 & 49 & 13 & 5 & 70 & 105 \\
Adh-1 & 0 & 14 & 11 & 3 & 28 & 105 \\
Adh-2 & 0 & 14 & 11 & 3 & 28 & 105 \\
Lap & 3 & 51 & 13 & 6 & 73 & 65 \\
Mdh-1 & 3 & 48 & 15 & 4 & 70 & 105 \\
Mdh-2 & 3 & 48 & 15 & 4 & 70 & 105 \\
Mdh-3 & 3 & 48 & 15 & 4 & 70 & 105 \\
Mdh-4 & 3 & 48 & 15 & 4 & 70 & 105 \\
6pg-1 & 3 & 53 & 15 & 6 & 79 & 36 \\
6pg-2 & 3 & 53 & 15 & 6 & 79 & 36 \\
G3pdh & 3 & 53 & 15 & 6 & 79 & 105 \\
\hline
\end{tabular}

Table 3. Allele frequency at eight polymorphic loci

\begin{tabular}{lccccccc}
\hline \hline \multirow{2}{*}{ Pgi-2 } & allele & I & II & Tôno & III & Total & \\
& $a$ & 0.67 & 0.82 & 0.68 & 1.00 & 0.79 & 0.03 \\
& $b$ & 0.33 & 0.18 & 0.32 & 0.00 & 0.21 & 0.09 \\
& $c$ & 0.00 & 0.00 & 0.00 & 0.00 & 0.00 & 0.85 \\
& $d$ & 0.00 & 0.00 & 0.00 & 0.00 & 0.00 & 0.03 \\
Pgm-1 & $a$ & 1.00 & 1.00 & 1.00 & 1.00 & 1.00 & 0.77 \\
& $b$ & 0.00 & 0.00 & 0.00 & 0.00 & 0.00 & 0.23 \\
Pgm-2 & $a$ & 0.00 & 0.00 & 0.00 & 0.00 & 0.00 & 0.17 \\
& $b$ & 0.67 & 0.50 & 0.57 & 0.50 & 0.52 & 0.83 \\
& $c$ & 0.17 & 0.30 & 0.23 & 0.50 & 0.30 & 0.00 \\
& $d$ & 0.17 & 0.20 & 0.20 & 0.00 & 0.18 & 0.00 \\
Lap & $a$ & 0.00 & 0.51 & 0.65 & 0.50 & 0.51 & 0.61 \\
& $b$ & 1.00 & 0.49 & 0.35 & 0.50 & 0.49 & 0.39 \\
Mdh-1 & $a$ & 0.00 & 0.00 & 0.00 & 0.00 & 0.00 & 0.08 \\
& $b$ & 1.00 & 1.00 & 1.00 & 1.00 & 1.00 & 0.92 \\
Mdh-4 & $a$ & 0.67 & 0.96 & 0.93 & 0.75 & 0.93 & 1.00 \\
& $b$ & 0.33 & 0.04 & 0.07 & 0.25 & 0.07 & 0.00 \\
Adh-2 & $a$ & - & 1.00 & 1.00 & 1.00 & 1.00 & 0.11 \\
& $b$ & - & 0.00 & 0.00 & 0.00 & 0.00 & 0.15 \\
& $c$ & - & 0.00 & 0.00 & 0.00 & 0.00 & 0.49 \\
& $d$ & - & 0.00 & 0.00 & 0.00 & 0.00 & 0.26 \\
Tpi-2 & $a$ & 1.00 & 1.00 & 1.00 & 1.00 & 1.00 & 0.50 \\
& $b$ & 0.00 & 0.00 & 0.00 & 0.00 & 0.00 & 0.50 \\
& & & & & & &
\end{tabular}

and nine (Pgi-2c, Pgi-2d, Pgm-1b, Pgm-2a, Mdh-1a, Adh$2 b, A d h-2 c, A d h-2 d$, and Tpi-2b) are restricted to the population of Tsushima. The other ten alleles coded by the eight polymorphic loci are common to both the Tôno and Tsushima populations.

The genetic measures of variability for each population are listed in Table 4. The overall gene diversity $(h)$ in the Tôno region is 0.087 , with the lowest diversity (0.076) occurring in the subpopulation Tôno-IV and the highest 
Table 4. Genetic variation in the populations of Chionanthus retusus

\begin{tabular}{|c|c|c|c|c|c|}
\hline $\begin{array}{c}\text { Population } \\
\text { No. }\end{array}$ & $\begin{array}{l}\text { Sample } \\
\text { size }\end{array}$ & $\begin{array}{c}\% \text { of loci } \\
\text { polymorphic }\end{array}$ & $\begin{array}{c}\text { Number of } \\
\text { alleles per } \\
\text { polymorphic locusæ }\end{array}$ & $\begin{array}{l}\text { Number of } \\
\text { alleles per locus }\end{array}$ & $\begin{array}{c}\text { Gene diversity } \\
(h)\end{array}$ \\
\hline Tôno-I & 3 & 17.6 & 2.30 & 1.24 & 0.087 \\
\hline Tôno-II & 54 & 22.2 & 2.25 & 1.28 & 0.083 \\
\hline Tôno-III & 15 & 22.2 & 2.25 & 1.28 & 0.089 \\
\hline Tôno-IV & 6 & 16.7 & 2.00 & 1.17 & 0.076 \\
\hline Tôno-total & 78 & 22.2 & 2.30 & 1.28 & 0.087 \\
\hline Tsushima & 105 & 38.9 & 2.86 & 1.72 & 0.149 \\
\hline
\end{tabular}

Table 5. Genetic identity and genetic distance between subpopulations of the Tôno region

\begin{tabular}{l|c|c|c|c}
\hline \hline I D & Tôno-I & Tôno-II & Tôno-III & Tôno-IV \\
\hline Tôno-I & - & 0.025 & 0.029 & 0.029 \\
\hline Tôno-II & 0.975 & - & 0.0018 & 0.0071 \\
\hline Tôno-III & 0.971 & 0.998 & - & 0.0118 \\
\hline Tôno-IV & 0.971 & 0.993 & 0.998 & - \\
\hline
\end{tabular}

* I\&D between the Tôno region and Tsushima: $\mathrm{I}=0.918, \mathrm{D}=$ 0.086 .
Table 6. Levels of genetic diversity of Chionanthus retusus

\begin{tabular}{l|c|c|c}
\hline \hline \multicolumn{1}{c|}{ Region } & $H_{T}$ & $H_{S}$ & $G_{S T}$ \\
\hline Tôno region* & 0.087 & 0.081 & 0.066 \\
\hline Tôno and Tsushima** & 0.164 & 0.118 & 0.280 \\
\hline
\end{tabular}

* among four subpopulations, ** between Tôno and Tsushima.

Table 7. Spatial autocorrelation coefficients (Moran's $I$ ) and the significances (P) of overall correlogram for the six alleles in chionanthus retusus in Tôno region

\begin{tabular}{lrlrrrrrrrrrr}
\hline \hline & $<5$ & $<10$ & $<15$ & $<20$ & $<25$ & $<30$ & $<35$ & $<40$ & $<45$ & $>45$ \\
\hline Pgi-1a & -0.08 & 0.03 & -0.17 & -0.08 & 0.27 & 0.10 & 0.22 & -0.11 & -0.22 & -0.20 & $\mathrm{~ns}$ \\
Pgm-2b & -0.06 & -0.13 & 0.06 & -0.09 & -0.18 & 0.11 & 0.00 & -0.05 & 0.09 & 0.01 & $\mathrm{~ns}$ \\
Pgm-2c & 0.00 & -0.03 & -0.11 & 0.03 & 0.04 & -0.08 & 0.40 & -0.35 & 0.12 & 0.22 & $\mathrm{~ns}$ \\
Pgm-2d & 0.09 & $-0.27^{*}$ & $0.16^{*}$ & $-0.23^{*}$ & 0.01 & -0.02 & 0.15 & 0.04 & -0.12 & -0.02 & $\mathrm{~ns}$ \\
Lap-a & 0.04 & -0.19 & 0.10 & -0.11 & 0.02 & -0.01 & -0.10 & -0.13 & -0.06 & -0.07 & $\mathrm{~ns}$ \\
Mdh-4a & -0.08 & -0.05 & -0.02 & -0.06 & -0.05 & -0.08 & 0.14 & 0.11 & 0.47 & $-{ }^{\dagger}$ & $\mathrm{ns}$ \\
Mean & -0.02 & -0.11 & 0.00 & -0.09 & 0.02 & 0.01 & 0.13 & -0.08 & 0.12 & -0.01 & \\
\hline
\end{tabular}

$* \mathrm{P}<0.05$. ${ }^{\dagger}$, no pair in this distance class due to missing data.

(0.089) occurring in Tôno-III. The population of Tsushima showed higher genetic diversity of 0.149 .

Nei's genetic identity and distance were calculated among the subpopulations of the Tôno region and between the Tôno and Tsushima populations (Table 5). The genetic identities among the subpopulations of the Tôno region ranged from 0.971 to 0.998 . The genetic identity between Tôno and Tsushima populations was 0.918 .

Table 6 shows the gene diversity statistics in the Tôno and Tsushima populations. The average heterozygosity $\left(H_{T}\right)$ of the population of Tôno is 0.087 , the average heterozygosity of each subpopulation $\left(H_{S}\right)$ is 0.081 , and the genetic divergence between the subpopulations $\left(G_{S T}\right)$ is 0.066. The $H_{T}, H_{S}$, and $G_{S T}$ values estimated between Tônototal and Tsushima are $0.164,0.118$, and 0.280 , respectively.

To compare the level of genetic diversity between Tôno and Tsushima, $t$-test was adopted. This test is usually not appropriate between two closely related populations which have historical interrelation in heterozygosity (Nei, 1987). But in this case, each population has been isolated from the other geographically long period, and their allele frequency on polymorphic loci seems to be independent. Thus $t$-test using sample variance can be acceptable (Nei, 1987). The result, $t=1.1482$ using all 18 loci, shows no significance between the genetic diversity of two populations. Also, paired $t$-test, using only 8 polymorphic loci, shows no significance with $t=1.1630$.

Spatial autocorrelation of genotypes in the Tôno region. Only three of the 60 Moran's I coefficients estimated were found to deviate significantly from $E(I)$ (Table 7). The $I$ values were significant only in the second to the fourth distance class of $P g i-2 d$. Although we performed spatial autocorrelation analysis at smaller intervals of distance class (e. g., $1 \mathrm{~km}$ and $2 \mathrm{~km}$ interval), most Moran's I's do not deviated from the expected values as with Table 7 (data not 
shown). None of the overall correlograms showed statistical significance according to Bonferroni's criteria (Table 7).

\section{DISCUSSION}

Genetic diversity within populations. The results of this study can be compared with the comprehensive reviews (Hamrick and Godt, 1989; Hamrick et al., 1992) of the levels and distribution of genetic diversity in seed plants. Genetic diversity within a population is influenced by its life history and the geographic range of the species.

C. retusus is that of a long-lived tall tree up to $30 \mathrm{~m}$ in height. According to Hamrick et al. (1992), populations of long-lived woody perennial species have on average $49.3 \%$ polymorphic loci and a gene diversity of 0.148 (calculated from 191 species). The Tôno population has lower levels of genetic diversity: $22.2 \%$ in $P(16.7-22.2 \%$ for subpopulations) and 0.087 in $h$ (0.076- 0.089 for subpopulations). The population of Tsushima also has a lower percentage of polymorphic loci, 38.9\%. However, there are three polymorphic loci each has four alleles, and the gene diversity of Tsushima, 0.149 is nearly equal to the average value for 191 species (Hamrick et al., 1992).

Widespread species tend to have higher proportions of polymorphic loci and higher gene diversity than geographically limited species (Karron, 1987; Hamrick et al., 1992). C. retusus is distributed somewhat regionally in East Asia, but its present distribution in Japan is narrow and relic. Compared to woody species with narrow geographic ranges, the subpopulations of the Tôno region have relatively lower levels of genetic diversity ( $22.2 \%$ polymorphic loci and 0.087 gene diversity for the total of subpopulations of the Tôno region, vs. $44.3 \%$ and 0.143 for the 61 species in Hamrick et al. [1992]). The values for 115 narrowly distributed seed plant species $-30.6 \%$ in $P$ and 0.105 in $h$ - are also higher than those of C. retusus in the Tôno region. But compared to the endemic species ( 0.056 for 26 woody endemics, 0.063 for 100 seed plants), the population of the Tôno region has a slightly higher gene diversity. The population of Tsushima shows rather higher genetic diversity. The percentage of polymorphic loci (38.9\%) is lower than that of narrow woody species $(44.3 \%)$, but the genetic diversity of the population of Tsushima (0.149) is comparable to that of narrow woody species (0.143). These comparisons may reflect that the populations of $C$. retusus in both Tôno and Tsushima have fewer polymorphic loci but each polymorphic locus keeps relatively high heterozygosity.

Because the fossil evidences suggest that the distribution of C. retusus was larger and continuously covering both Tôno and Tsushima, the initial genetic variation should have been shared. But in the present data, the population of the Tôno region has less than $60 \%$ (58.4\%) of genetic diversity and fewer polymorphic loci than those of Tsushima. And in contrast to only three specific alleles in the Tôno populations, nine alleles are Tsushima specific. While re- sults of the $t$-test show no significant difference between two regions in genetic diversity, the data give an impression that the population in the Tôno region has been loosing the genetic variation while isolated.

Genetic differentiation between populations. Among the Tôno region's subpopulations, the lowest genetic identity was 0.971 between both Tôno-I and III, and Tôno-I and IV, while the highest was 0.998 between Tôno-II and III. And the $G_{S T}$ among the subpopulations of the Tôno region was 0.066 . These values show that the genetic differentiation between the subpopulations in the Tôno region is very small.

The genetic identity between the Tôno and Tsushima populations was 0.918 , a lower value than those among the Tôno subpopulations, but comparable to those for the intraspecific populations of other seed plant species (cf., Gottlieb, 1981; Crawford, 1983). The highest value of $G_{S T}$ reported by Hamrick and his colleagues (Hamrick et al., 1992 ) is 0.248 for 52 endemics of seed plants, which is still lower than that between the $C$. retusus populations of Tôno and Tsushima $\left(G_{S T}=0.280\right)$. This indicates the possibility that the gene flow between these two regions has been blocked for a long period and genetic differentiation is occurring.

Spatial autocorrelation of genotypes in the Tôno region. We could not find any spatial genetic structure of $C$. retusus in the Tôno region by spatial autocorrelation analysis. This result coincides with the fact that the proportion of the genetic diversity $\left(G_{S T}\right)$ is very small among subpopulations of Tôno region (Table 6).

Although $C$. retusus stands are currently only scattered over the Tôno, in former times they probably were more continuous in this region. Over the past several decades, the habitats of $C$. retusus have been destroyed to make room for housing developments, golf courses, and so on. Because we electrophoretically analyzed leaves from mature trees in this study, it is possible that we analyzed the genetic structure of the populations established before more than 20-30 years prior to these habitat changes, when C. retusus probably distributed more continuously and its gene flow among stands probably occurred more easily. In present, each stand is more isolated one another in the Tôno region than before. Because C. retusus is a long-lived woody tree, it is possible that we could not detect the effect of the recent fragmentation. To estimate precise influence of habitat fragmentation, a same analysis on young seedlings should be conducted.

Maintenance of genetic diversity and structure. Considering from the present distribution range and the fossil records, the populations of Tôno and Tsushima are both relic. The population size of Tsushima is large enough to maintain genetic diversity, however, the population of 
the Tôno region has less than 200 individuals in spite of its relatively large area, and the gene diversity of Tôno seems lower. The decrease of the gene diversity could be occurred in long term period after isolation or in short term with recent habitat fragmentation. But the lack of differentiation in genetic structure suggests the possibility that the influence of habitat fragmentation is not revealed yet. McDonald and Hamrick (1996) examined the genetic variation of perennial plants and found that perennial endemics of Florida scrub have rather higher genetic diversity compared to the mean of other endemic species. They proposed two causal factors. "First, loss of the habitats is recent but rapid and continuing. Second, because these plants are long-lived woody perennial, lags may occur in the genetic response to changing conditions." It seems likely that these two factors were also working on $C$. retusus of the Tôno region.

C. retusus may live for several decades. It is therefore possible that the genetic variation and structure observed in this study were formed more than a few decades of years ago, at a time when the species was distributed continuously over the Tôno region. At present, gene flow among the extant stands in the Tôno region seems to be restricted caused by habitat fragmentation. As a result, the genetic diversity of the $C$. retusus population should be under continuing influence of random drift, which is likely to further genetic paucity in the Tôno region.

C. retusus is now considered an endangered plant in Japan (anonymous, 1989), because of habitat destroying in the Tôno region. To prevent its extinction, transplantation from Tsushima to the Tôno region is planned by local government. However, as shown in this study, genetic differentiation has already occurred between these two isolated populations. Thus, such a genetically disturbing transplantation is a rough-and-ready way for conservation. Because the population of $C$. retusus in the Tôno region still maintains a certain genetic diversity, another method, such as habitat maintenance and artificially genetic intermingling between stands, should be adopted to preserve and increase the population size in Tôno.

The authors thank T. Ohta for his invaluable information and advice and $\mathrm{T}$. Yahara for his critical reading of the manuscript and accurate comments. A part of the leaf material from Tsushima was kindly collected by S. Matsumoto, to whom we also express our gratitude. We also thank S. Noshiro for his valuable information and M. Masuda-Maki for her analysis of the data. This study was supported in part by the Grant-in-Aid for Scientific Research (no. 08640884 to KU, no. 07304081 to MM) from the Ministry of Education, Science, Sports, and Culture of Japan, fund from Nippon Seimei Insurance (1991, to KU), and by the Global Environment Research Fund (F-1) of the Japanese Environment Agency (to MM).

\section{REFERENCES}

Anonymous (1989) Current status of threatened plants in Japan (Plant Red Data Book). Nature Conservation Society of Ja- pan, WWF Japan and the Editorial Committee for Current Status of Threatened Plants in Japan.

Baas, P., Esser, P. M., van der Westen, M. E. T., and Zandee, M. (1988) Wood anatomy of the Oleaceae. IAWA Bull. New Ser. 9, 103-182.

Billington, H. L. (1991) Effect of population size on genetic variation. Conserv. Biol. 5, 115-119.

Cardy, B. J., Stuber, C. W., and Goodman, M. M. (1981) Techniques for starch gel electrophoresis of enzyme from maize (Zea mays), revised. Inst. Stat. Mimeogr. Ser. 1317R, North Carolina State Univ., Raleigh, NC.

Chuang, T-I., Chao, C.-Y., Hu, W.-L., and Kwan, S.-C. (1962) Chromosome numbers of the vascular plants of Taiwan I. Taiwania 8: 51-66.

Crawford, D. J. (1983) Phylogenetic and systematic inferences from electrophoretic studies. In: Isozymes in Plant Genetics and Breeding, Part A (eds.: S. D. Tanksley and T. J. Orton), pp. 257287. Elsever Sci. Publ. Co., Inc., New York.

Hamrick, J. L., and Godt, M. J. W. (1989) Allozyme diversity in plant species. In: Plant Population Genetics, Breeding, and Genetic Resources. (eds.: A. H. D. Brown, M. T. Clegg, A. C. Kehler, and B. S. Weir), pp. 43-63. Sinauer Assoc., Sunderland, MA.

Hamrick, J. L., Godt, M. J. W., and Sherman-Broyles, S. L. (1992) Factors influencing levels of genetic diversity in woody plant species. New For. 6: 95-124.

Heywood, J. S. (1991) Spatial analysis of genetic variation in plant populations. Annu. Rev. Ecol. Syst. 22: 335-355.

Gottlieb, L. D. (1981) Electrophoretic evidence and plant populations. Prog. Phytochem. 7: 1-46.

Kato, T. (1990) Taxonomical studies on the Hypericum pseudopetiolatum complex. IV. Allozyme diversity and phylogenetic inference. J. Fac. Sci. Univ. Tokyo Sect. III Bot. 14: 341368.

McCleanaghan, L. R. J., and Beauchamp, A. C. (1986) Low genetic differentiation among isolated populations of the Californian fan palm (Washingtonia filifera). Evolution 40: 315-322.

McDonald, D. B., and Hamrick, J. L. (1996) Genetic variation in some plants of Florida scrub. Am. J. Bot. 83: 21-27.

Moran, G. F., and Hopper, S. D. (1983) Genetic diversity and the insular population structure of the rare granite rock species, Eucalyptus caesia Benth. Aust. J. Bot. 31: 161-172.

Nei, M. (1972) Genetic distance between populations. Am. Nat. 106: $283-292$.

Nei, M. (1973) Analysis of gene diversity in subdivided populations. Proc. Natl. Acad. Sci. USA 70: 3321-3323.

Nei, M. (1987) Molecular Evolutionary Genetics. Columbia Univ. Press, New York.

Noshiro, S., and Fujine, H. (1997) Holocene fossil woods of Chionanthus retusus Lindl. et Paxton from Southern Gifu Prefecture, Central Japan. Jpn. J. Histor. Bot. 5: 39-42.

Sakai, A. K., and Oden, N. L. (1983) Spatial pattern of sex expression in silver maple (Acer saccharum Marsh.) stands. Am. Nat. 122: 489-508.

Sax, K., and Abbe, E. C. (1932) Chromosome numbers and the anatomy of the secondary xylem in the Oleaceae. J. Arnold Arbor. 13: 37-48.

Sokal, R. R., and Oden, N. L. (1978) Spatial autocorrelation in biology. I. Methodology. Biol. J. Linn. Soc. 10: 199-228.

Soltis, D. E., Haufler, D. C., Darrow, D. C., and Gastony G. J. (1983) Starch gel electrophoresis of ferns: a complication of grinding buffers, gel and electrode buffers, and staining schedules. Am. Fern J. 73: 9-27.

Soltis, P. S., and Soltis D. E. (1987) Population structure and estimates of gene flow in the homosporous fern Polystichum munitum. Evolution 41: 620-629. 
Stearn, W. T. (1976) Union of Chionanthus and Linociera (Oleaceae). Ann. M0. Bot. Gard. 63: 355-357.

Taylor, H. (1945) Cyto-taxonomy and phylogeny of the Oleaceae. Brittonia 5: 337-367.

Ueda, K. (1989) Phytogeography of Tokai Hilly Land Element I. Definition. Acta Phytotax. Geobot. 40: 190-202 (in Japanese).

Ueda, K. (1996) Androdioecism in Chionanthus retusus (Oleaceae). J. Phytotax. Taxon. 44: 91-92. van Treuren, R., Bijlsma, R., van Delden, W., and Ouborg, N. J. (1991) The significance of genetic erosion in the process of extinction. I. Genetic differentiation in Salvia pratensis and Scabiosa columbia in relation to population size. Heredity 66: $181-190$.

Wartenberg, D. (1989) SAAP ver. 4.3. Exeter, Setauket.

Yahara, T., Kawahara, T., Crawford, D. J., Ito, M., and Watanabe, K. (1989) Extensive gene duplications in diploid Eupatorium (Asteraceae). Am. J. Bot. 76: 1247-1253. 